Bente Flaten, barnevernspedagog, NordAurdal kommune.
Marit Sundvold Brustad, psykiatrisk sykepleier, Sør-Aurdal kommune.
Hanne Svendsen, psykiatrisk sykepleier, $\emptyset$ ystre Slidre kommune.
Mette Gjevre, barne-

vernspedagog og leder

for Interkommunal barneverntjeneste i valdres.

\title{
Tverrfaglig samarbeid i barnevernsaker
}

\author{
Samarbeid med barnets sosiale nettverk allerede ved oppstarten av barnevernsaker kan spare tid og ressurser.
}

$\mathbf{V}$ år visjon er at kommunale tjenester rettet mot barn og unge i Valdres har åpen dialog som grunnholdning i tverrfaglig samarbeid. Artikkelen tar for seg faktorer vi mener kan styrke det tverrfaglige samarbeidet i en barnevernssak. Artikkelen bygger på erfaringer fra to fagdager i Valdres høsten 2010 og våren 2011. Et fokusgruppeintervju ble holdt mellom fagdagene. Deltakerne på fagdagene og fokusgruppen kom fra barneverntjenesten, helsestasjon, psykologiskpedagogisk tjeneste og psykisk helsearbeid.

\section{Nettverksarbeid}

Elisabeth Strøm fra barneverntjenesten i Bærum møter familien med et sosialt nettverksperspektiv. Strøm beskriver nettverksarbeid som å bruke barnets eget nettverk som ressurs for å styrke familiens evner og muligheter til å gi barnet best

\section{Hovedbudskap}

Artikkelforfatterne hevder det kan være mye å hente av kunnskap, tid og ressurser ved å jobbe med å bedre det tverrfaglige samarbeidet i barnevernsaker. Starter man med tverrfaglig samarbeid allerede før undersøkelsesfasen legges et grunnlag videre i saken.

\section{Søkeord}

Les mer og finn litteraturhenvisninger på våre nettsider. ) Barn | Tverrfaglighet | Samarbeid mulig omsorg (1). Det sosiale nettverket er barnets nærmeste sosiale relasjoner og derfor relevant å bruke for å definere hva som er problemet (2). Alle spørsmål drøftes åpent med familien til stede. Her analyseres problemet, og planlegging av tiltak drøftes og blir bestemt. Vi mener man kan hente mye kunnskap, tid og ressurser ved å $ø$ ke det tverrfaglige samarbeidet i barnevernssaker. Starter man med tverrfaglig samarbeid allerede før undersøkelsesfasen, legger man et godt grunnlag for å arbeide videre med saken. Veileder for barn og unge i kommunene poengterer at det er et mål å sikre at barn og voksne skal møte et hjelpeapparat som evner å samarbeide til barnets beste (3). Nettverksarbeid kan gjennomføres på forskjellige måter. Nettverksmøtet kan for eksempel inngå som oppstartsmøte i undersøkelsesfasen, hvis foreldrene ønsker det.

\section{Spørsmål}

Vi stilte følgende spørsmål til fokusgruppen, som besto av fem deltakere fra barnevernet, helsestasjon og psykisk helsearbeid:

\I hvilken grad har du som fagperson vært delaktig i en undersøkelse i en barnevernsak, og hvilke erfaringer har du gjort deg, eventuelt kjennskap til andres erfaringer?

, Hvor ligger utfordringene i samarbeidet, slik det er i dag?

I Har du noen tanker om hvordan undersøkelsesfasen kunne vært gjennomført? Er det noe du er opptatt av, som du ikke har fått sagt noe om i dag?
Da vi bearbeidet stoffet fant vi fire hovedområder. Disse områdene utgjør artikkelens kjerne. Det første aspektet omhandler samarbeidende instansers ønske om å delta og bidra med sin kompetanse og erfaring. Flere opplever at barneverntjenesten i liten grad kommuniserer med dem som har daglig eller mer sporadisk kontakt med barnet og familien. Det å få en skriftlig henvendelse hvor man opplyses om sin plikt til å gi informasjon, oppleves ikke som reelt samarbeid. Det andre området vi har trukket fram er fagfolks ønske om og behov for å kjenne til hverandre. Formelle og uformelle møteplasser der fagfolk opplever kontakt med hverandre blir sett på som nyttig for et samarbeid på tvers av tjenester. Opplevelsen av barneverntjenestens fokus på formular og språk av juridisk karakter er det tredje området. Informantene mener henvisning til paragrafer uten videre forklaring vanskeliggjør samarbeidet, både med fagfolk og overfor familien. Det fjerde og siste området omhandler fagfolks følelser i barnevernssaker. Fagpersonen påvirkes i ulik grad og på forskjellig vis av den daglige kontakten med sårbare mennesker og deres historier. Samtidig har fagpersonen med seg egne erfaringer som påvirker relasjonen til andre. Heretter bruker vi informanter når vi viser til uttalelser fra fokusgruppeintervjuet, og fagfolk når vi viser til uttalelser fra fagdagene.

\section{Åpen dialog}

Den kommunale barneverntjenesten skal ifølge Lov om barneverntjenester (4) samarbeide med andre sektorer og 


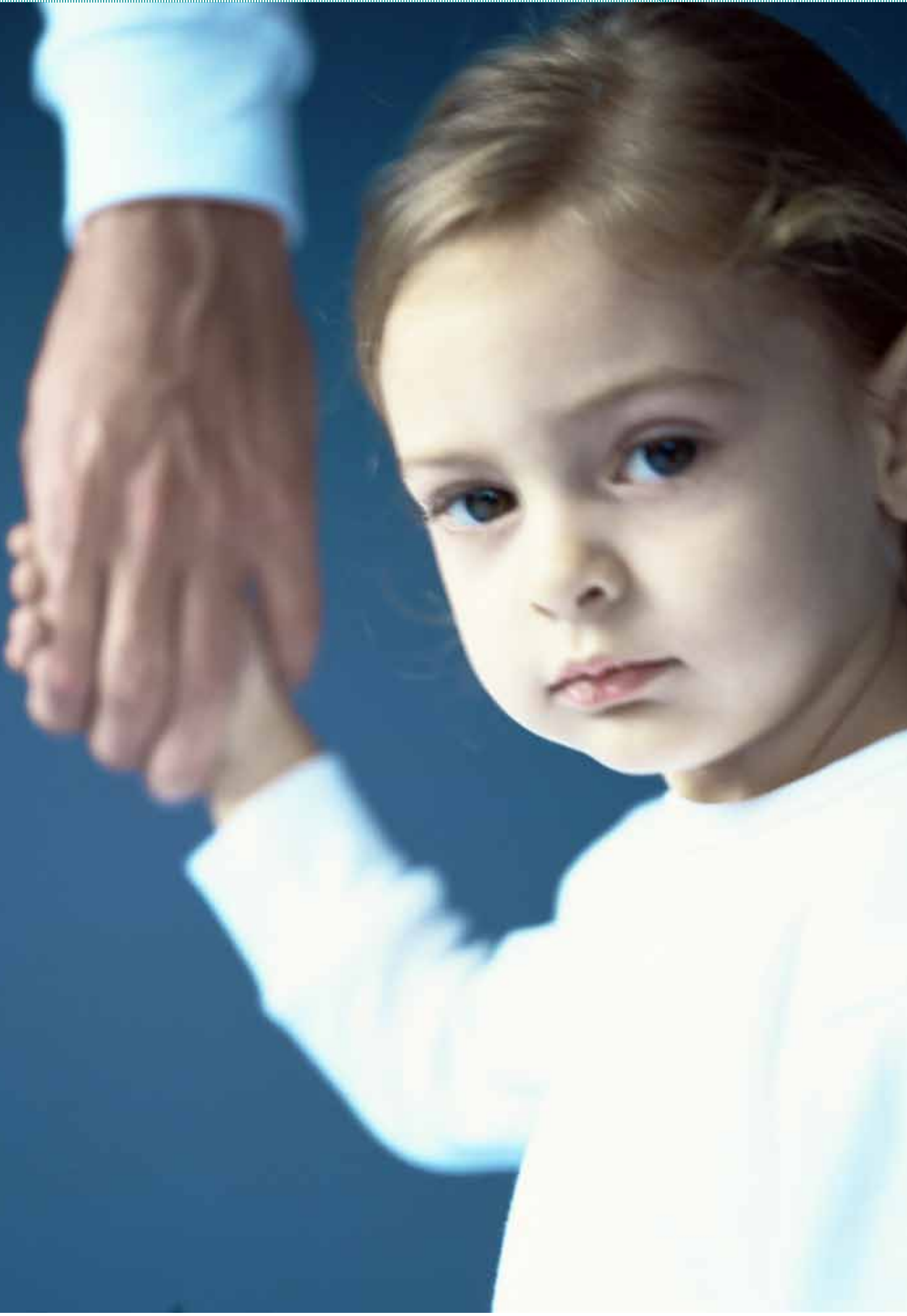

GIR TRYGGHET: Barnets nettverk kan være alt fra fastlege, helsesøster, lærer på skole eller i barnehage til venner og familie. Illustrasjonsfoto: Colourbox 
forvaltningsnivåer der dette er til barnets beste. Informanter og fagfolk generelt opplever samarbeidet som tilfeldig. Barnevernloven tillater stor grad av skjønnsutøvelse. Den enkelte saksbehandler vurderer i hvor stor grad man bør opprette samarbeid med andre instanser. Samarbeidsprosesser blir oppfattet som personavhengig og med varierende kvalitet (5). Barn som mottar tjenester fra barneverntjenesten er også kommunens ansvar, ikke bare barnevernets. Det å gi utsatte barn og unge tilstrekkelig hjelp kan være en for stor oppgave for barneverntjenesten alene. Dette er barn som har behov for helhetlig og koordinert hjelp til rett tid (6).

\section{Lav terskel}

Det er utfordrende og vanskelig å melde bekymring for et barn og dets familie. Det er vanskelig å vurdere hvor alvorlig et forhold skal være for at det skal være en sak for barnevernet. Det kan synes som om terskelen er nokså høy før meldeplikten inntrer. Informantene ønsker generelt et tettere samarbeid, og en lavere terskel både

\section{«Alle spørsmål drøftes åpent med familien til stede.»}

for å ta kontakt, samt for å invitere barnevernet inn på egen arena. Barnevernet på sin side er opptatt av tidlig intervensjon. Man opplever at det å komme tidlig inn med tiltak i en familie blant annet reduserer antallet ungdom med alvorlige psykiske lidelser (7).

\section{Det første møtet}

Når barneverntjenesten mottar melding som de beslutter å undersøke, er målet å framskaffe et så fullstendig bilde av barnet og familien som mulig. Her er både det private og profesjonelle nettverket viktige samarbeidspartnere. De er i kontakt med barnet og familien i ulike situasjoner. De har skapt seg et inntrykk av hvordan familien fungerer generelt, og hvordan barnet fungerer spesielt. Det første møtet barneverntjenesten har med familien er et viktig møtepunkt, der man danner relasjoner og utveksler informasjon. Allerede her er det hensiktsmessig å involvere samarbeidspartnere. Flere barneverntjenester har sett nytten av å invitere meldeinstans til dette første møte. Både familien selv og tjenesteapparatet gir uttrykk for at denne innfallsvinkelen bidrar til et bedre og mer positivt samarbeid videre i prosessen. Her får familie og melder anledning til å fortelle sin historie og muligheten for å oppklare misforståelser til stede. Etter dette møtet ligger forholdene til rette for at barneverntjenesten kan danne seg et bilde av problematikken i denne aktuelle familien. De har skaffet seg et godt grunnlag for den videre prosessen.

Et skritt videre er å gi familien mulighet til å velge oppstartsmøte som en måte å gjennomføre undersøkelsen på. Her møtes det private og offentlige nettverket for å belyse barnets og familiens situasjon. Alle stemmer blir hørt og vurdert opp mot innholdet i meldingen. Saksbehandler blir da tilstrekkelig opplyst til å konkludere undersøkelsen i møtet, noe som medfører en kortere undersøkelsesprosess (1). I tillegg blir samarbeidspartnere inkludert og får samme informasjon som familien. Dette gir trygghet og tilfredshet for alle parter (5).

\section{Informasjonsplikt}

Tradisjonelt har barneverntjenesten sendt brev for å innhente opplysninger til de instansene som er involvert i barnet og familien. Informantene har forståelse for barnevernets behov for skriftlig dokumentasjon. Likevel foretrekker de å møtes på tvers av etatene med mulighet til å drøfte opplysninger, også med familien til stede. Når det gjelder skriftlig tilbakemelding opplever de det som skummelt å svare på spørsmålene. Dette fordi muligheten til å utdype uttalelsen ikke er til stede. Andre mener de ikke alltid har forutsetning for å besvare spørsmålene.

Nylig vedtok regjeringen en lovendring som ivaretar melders interesser ved å gi barneverntjenesten plikt til å gi tilbakemelding ved mottatt melding, samt når undersøkelsen er avsluttet. Samtidig bør barneverntjenesten etterstrebe å be om samtykke fra foreldre for å kunne dele viktig og relevant informasjon. De aller fleste foreldre er positive til at barneverntjenesten utveksler informasjon når de opplever at dette er for å hjelpe barnet deres. Informasjon og opplevelse av gjensidig tillit bidrar til mindre frustrasjon og konflikter mellom samarbeidspartnerne. Partene får tilstrekkelig kunnskap til å kunne ivareta sine arbeidsoppgaver på en tilfredsstillende måte (5). Taushetspliktbestemmelsene i barnevernlovens § 6-7 skal ikke være til hinder for barnets beste (4).

\section{Informanter}

Det er ikke bare i oppstart av en undersøkelse at fagfolk ønsker et samarbeid og å bidra med sin kompetanse. Informantene mener de også bør få uttale seg når man skal trekke konklusjoner av undersøkelsen og iverksette tiltak. En informant hadde gjennom sitt virke en relasjon til en familie.
Da den aktuelle familien ble en sak for barnevernet, føltes det som om den «glapp ut av hendene» hennes. Den innsatsen informanten hadde lagt ned, føltes ikke lengre som viktig. Informanten var ikke lenger en del av tiltaksapparatet i familien. Da barneverntjenesten skulle vurdere tiltak, ble hun heller ikke bedt om å uttale seg. Dette opplevde hun som rart. I slike situasjoner kan barneverntjenesten gå glipp av viktig informasjon. Dialog kan føre til at man unngår tiltak som allerede er forsøkt og som ikke fungerer.

\section{Felles møteplasser}

Fagfolk opplever at det er lettere å ta kontakt med representanter for andre tjenester når man har møtt dem før. Flere sier at det å ha sett, hørt og snakket med den fagpersonen man kontakter eller blir kontaktet av, er nyttig. Møteplasser kan være på forskjellige arenaer. Det kan være fagfolk og familien i samme møte eller møter der fagfolk drøfter saken uten familien, fortrinnsvis med familiens godkjennelse. Eller man kan diskutere saken anonymt.

Det ble sagt at felles møter bør ha som mål å utvikle og utfordre egen praksis. Felles møteplasser bør legge grunnlag for å reflektere over om praksis er god nok eller om den trenger vitalisering. For fagfolk som skal hjelpe og støtte familien, er det viktig å være oppmerksom på holdninger, perspektiver og refleksjon rundt egen praksis. Informantene var enige om at det er viktig at fagfolk blir kjent og skaper tillit seg imellom. Trygghet og gjensidig tillit mellom personene i nettverket, både det private og det profesjonelle, er en forutsetning (3).

Felles møteplasser kan bidra til at vi klarer å gi slipp på frykten for å miste kontrollen i en sak. Seikkula og Arnkil sier at når flere aktører møtes for å diskutere og behandle en bekymringsfull situasjon, er det vanskelig for én person å kontrollere tingenes tilstand (2). Informanter sier at barnevernet må ha tillit til at andre fagfolk kan bidra til å finne løsninger. For å løse sine oppgaver, er barneverntjenesten avhengig av å samarbeide med andre offentlige tjenester og instanser.

\section{Formelt språk}

I fokusgruppeintervjuet kom det frem at barnevernet oppleves som lukket og formelt. Språk er makt. Bruk av fagterminologi og henvisning til lovverk kan skape avstand og bidra til å opprettholde fordommer. Dette er fordommer og forventninger skapt blant annet av media, der barnevernet enten tar omsorgen for barn eller har sviktet. Barnevernet har både en kontroll- 
og hjelpefunksjon. Familien, barnevernet og deres samarbeidspartnere har plikter regulert gjennom lovverket som skal sikre barnets rettigheter. Dette plikter barnevernet å opplyse om gjennom å henvise til gjeldende paragrafer. Kontrollfunksjonen er en sentral del av tjenesten, men i senere år har det vært en dreining av fokuset. Barnevernet ønsker i større grad å fremstå som en samarbeidspartner som skal være til hjelp for familier som har det vanskelig. I denne sammenheng mener vi at språket er et viktig moment når vi snakker om tverrfaglig samarbeid i barnevernssaker.

På den siste fagdagen ble barnevernet utfordret til å finne tiltak som kan minske denne avstanden. De så selv at det var mulig å bli mer bevisst på språket, både muntlig og i brev som sendes til familier og samarbeidspartnere. De mente det var viktig å finne en balanse mellom å snakke et forståelig språk og beholde identitet og faglig autoritet. Språket er en del av den faglige identiteten, og derfor er det ikke hensiktsmessig å kutte ut alle begreper. Justering av språket kan indikere hvor langt man er kommet i å utvikle det tverrfaglige samarbeidet (8). Å forstå hva ord og paragrafer betyr, skaper trygghet både for familien og samarbeidspartnerne.

Språket vil også endre karakter når man snakker om barnet og familien med nettverket til stede. Å delta i et møte om seg selv, sine barn og sin familie er en direkte intervensjon i menneskers liv. Det er et minstekrav at bruker kommer styrket ut av slike møter. Om man ønsker et godt og fruktbart samarbeid bør språket justeres slik at alle forstår hva som blir sagt og føler seg likeverdige.

\section{Fagfolks følelser}

I intervjuet beskrev informantene egne følelser underveis i prosessen i en barnevernssak. Utfordrende følelser kan virke som en viktig personlig faktor i arbeidet. Selv om foreldrene er innforstått med at det blir sendt melding til barnevernet, kan relasjonen mellom den profesjonelle og familien komme i en kritisk fase. Informantene beskriver en følelse av å være «den slemme», og ønsker å dele meldingsansvaret med flere instanser. Utsagnet antyder en følelse av å sette familien i en krisesituasjon, at de bidrar til å gjøre vondt verre. Samtidig er det en påkjenning å se at barn utsettes for omsorgssvikt. Ifølge Lov om helsepersonell har fagfolk plikt til å sende bekymringsmelding, selv om den kan oppleves som belastende (9). Fagfolk må ha tillit til at krisen kan føre til nye muligheter.

Informantene ønsket å bli bedre ivaretatt av barneverntjenesten, og beskrev samtidig at det er viktig med støtte fra egen tjeneste. Det er viktig å kunne møtes i krisen når alle har det som vanskeligst. En samtale i en smertefull situasjon er et godt utgangspunkt for dialog. Det er lettere å mobilisere nettverket i en krisesituasjon. Tidlig i prosessen er det også lettere å innta en åpen holdning til problemet (10). Denne muligheten til åpen dialog tidlig i prosessen er lite brukt i barneverntjenesten.

Informantene antydet at hindringen for en åpen dialog ligger mer hos fagfolk enn hos foreldrene. Det kan være vanskelig for fagfolk å utlevere bekymringene de har for barnet $\mathrm{i}$ et åpent møte. Informantene beskrev et åpent møte med profesjonelle og familie som utfordrende, men positivt. De beskrev at de kunne være utrygge på sine faglige begrunnelser og at de tenker mye på hva andre fagfolk mener om deres utsagn.

Fagfolk mener det kan være hensiktsmessig å ha et oppstartsmøte i barnevernsaker. Strøm mener det er viktig at fagfolk som sender bekymringsmelding ikke lener seg tilbake, men tvert imot er på tilbudssiden og bidrar med sin kunnskap (1). Dette er i tråd med informantenes ønske. Et åpent møte med familien til stede kan gjenopprette et tillitsforhold. Det skaper trygghet å vite at noe skjer i saken. Fagfolk opplever at barnevernet kan være tause i inntil tre måneder. Dette skaper frustrasjon og hemmer muligheten til å bruke krisen som ressurs.

\section{Overinvolvering}

Informantene sa de opplevde det som skummelt å formidle sin bekymring i et stort møte. De vegrer seg for å snakke fritt fordi de frykter det skal brukes imot dem. En slik skepsis har sannsynligvis flere årsaker. Det kan blant annet være en konsekvens av å ha jobbet med tunge saker over flere år. Fagfolk som blir utsatt for negative historier om mennesker over tid, kan bli svekket i sin grunnleggende tillit til verden. Mangel på tillit kan være en hindring for samhandling. Samtidig når informantene beskriver en redsel for at et utsagn kan påvirke relasjonen, kan dette være uttrykk for en emosjonell smittefunksjon. Den andre personens glede smitter, og det samme gjør frykt, sorg og entusiasme (2).

Dersom fagfolk erkjenner vanskelige følelser hos seg selv, er det viktig at det finnes et forum på arbeidsstedet der man tør å snakke om dette. Veiledningsgrupper eller nettverksmøteforum kan være en slik arena. Fagfolk som klarer å kjenne på sitt eget følelsesliv, vil i større grad være i stand til å tone seg følelsesmessig inn på barn og voksne i sitt arbeid (12).
Belastning over tid kan føre til at man ikke orker å ta alvoret i barnas situasjon inn over seg. Eller motsatt, at det er vanskelig å legge fra seg bekymringen for barna. Alvorlige følelsesmessige konsekvenser for fagfolk kan være distansering, eller overinvolvering og traumatisering (13). Dette er faktorer og motsetninger som helt klart hemmer et samarbeid. Disse følelsesmessige reaksjonene kan lett ignoreres av en selv eller andre. Dette er utfordrende, og det krever mot å gjøre en kollega eller ansatt oppmerksom på dette på en god måte.

\section{«Språk er makt.»}

Det er vårt eget og arbeidsgivers ansvar å sørge for at det blir tatt faglig og menneskelig hånd om de risikoene det innebærer å arbeide med barnevernsaker (11). Fagfolk i Valdres er enige i at veiledning er et viktig tiltak. Det vil gi faglig trygghet og utvikling som fagperson. Bevissthet omkring egne følelsesmessige utfordringer kan brukes som redskap i møte med andre.

\section{Veien videre}

Vårt ønske for fremtiden er at kommunale tjenester rettet mot barn og unge i Valdres har åpen dialog som grunnholdning i tverrfaglig samarbeid. Dette mener vi øker muligheten for tidlig intervensjon og mer helhetlig hjelp. Oppstartsmøte som nettverksmøte er å ta tidsperspektivet på alvor. Ved å bruke åpen dialog tidlig tar man familiens opplevde krise på alvor. Da vil også energien i fagfolks ønske om delaktighet forløses, samtidig som undersøkelsesperioden vil oppleves som mindre belastende. IIII

\footnotetext{
LITTERATUR

Strøm E. I Bærum er nettverksmøtet en del av det helhetlige arbeidet. www. ks.no/portaler/Sammen-for-barn-og-unge. (24.03.2011).

2. Seikkula J, Arnkil TE. Nettverksdialoger. Oslo: Universitetsforlaget, 2007. Helsedirektoratet IS-1405. Psykisk helsearbeid for barn og unge i kommunene. Oslo: 2007.

LOV 1992-07-17 nr. 100 Lov om barneverntjenester

5. Sammen for barn og unge- bedre samordning av tjenester for barn og unge. Oppsummering av evaluering fase 1. NOVA på oppdrag fra KS-BLD

6. NOU 2009:22 Det du gjør, gjør det helt. Bedre samordning av tjenester for utsatte barn og unge.

7. Kvello $\emptyset$. (2007). Utredning av atferdsvansker, omsorgssvikt og mishandling. Oslo: Universitetsforlaget, 2007.

8. Lauvås K, Lauvås P. Tverrfaglig samarbeid- perspektiv og strategi. Oslo: Universitetsforlaget, 2009

LOV 1999-07-02-64 Lov om helsepersonell

. Seikkula J. Ápne samtaler. Oslo: Tano-Aschehoug, 2002

Bang S. Rørt, rammet, rystet. Oslo: Gyldendal akademisk, 2009.

. Aubert AM, Bakke IM. Utvikling av relasjonskompetanse. Oslo: Gyldendal akademisk, 2008

3. Bøe TD, Thomassen A. Fra psykiatri til psykisk helsearbeid. Oslo: Kunnskapsforlaget, 2009.
}

Fagartikler kan sendes til torhild.apall@sykepleien.no 